\title{
THE INFLUENCE OF INDIVIDUAL DETERMINANTS IN THE DELAY OF THE TUBERCULOSIS DIAGNOSIS
}

\author{
Débora Raquel Soares Guedes Trigueiroํㅜ, Jordana de Almeida Nogueira², Lenilde Duarte de Sá3, Aline \\ Aparecida Monroe ${ }^{4}$, Ulisses Umbelino dos Anjos ${ }^{5}$, Tereza Cristina Scatena Villa ${ }^{6}$, Daiane Medeiros da Silva ${ }^{7}$ \\ Sandra Aparecida de Almeida ${ }^{8}$
}

\footnotetext{
${ }^{1}$ Ph.D. candidate, Graduate Nursing Program at Universidade Federal da Paraíba (UFPB). João Pessoa, Paraíba, Brazil. E-mail: E-mail: deborasgt@hotmail.com

${ }^{2}$ Ph.D. in Nursing. Adjunct Professor at UFPB. João Pessoa, Paraíba, Brazil. E-mail: jalnogueira31@gmail.com

${ }^{3}$ Ph.D. in Nursing. Adjunct Professor at UFPB. João Pessoa, Paraíba, Brazil. E-mail: sa_lenilde@gmail.com

${ }^{4}$ Ph.D. in Nursing. Professor, Department of Maternal-Infantand Public Health Nursing, Universidade de São Paulo at Ribeirão Preto College of Nursing (USP). São Paulo, São Paulo, Brazil. E-mail: alinemonroe@yahoo.com.br

${ }^{5}$ Ph.D. in Statistics. Adjunct Professor at UFPB. João Pessoa, Paraíba, Brazil. E-mail: ulisses@de.ufpb.br

${ }^{6}$ Ph.D. in Nursing. Full Professor at USP. São Paulo, São Paulo, Brazil. E-mail: tite@eerp.usp.br

${ }^{7}$ Ph.D. candidate, Graduate Nursing Program at UFPB. João Pessoa, Paraíba, Brazil. E-mail: daianemedeiros19@hotmail.com

${ }^{8}$ Ph.D. candidate, Graduate Nursing Program at UFPB. João Pessoa, Paraíba, Brazil. E-mail: sandraalmeida124@gmail.com
}

\begin{abstract}
Analyzes the influence of individual determinants on the service usage pattern to define the time it takes for tuberculosis patients to seek care in order to discover their diagnosis. Cross-sectional research undertaken in a Northeastern capital of Brazil, involving 101 patients. The variables were submitted to statistical treatment through median and Mann-Whitney and Kruskal-Wallis non-parametric tests. A median 20 days was estimated for the patients' general delay, showing that single individuals who had less than eight years of study and were unemployed were the ones who delayed most in seeking a health service ( 30 days). The theoretic model used confirmed the presence of predisposing factors that favor the inequalities in the search for and obtainment of care. The inclusion of the subjective dimension in the guarantee of integral care can contribute to the renewal of practices and reduction of iniquities for individuals affected by tuberculosis.
\end{abstract}

DESCRIPTORS: Tuberculosis. Delayed diagnosis. Health services accessibility.

\section{A INFLUÊNCIA DOS DETERMINANTES INDIVIDUAIS NO RETARDO DO DIAGNÓSTICO DA TUBERCULOSE}

RESUMO: Analisa a influência dos determinantes individuais sobre o padrão de utilização de serviços como definidora do intervalo de tempo que o doente de tuberculose demora em buscar assistência para descobrir seu diagnóstico. Pesquisa seccional, realizada em capital do Nordeste brasileiro, envolvendo 101 doentes. As variáveis foram submetidas a tratamento estatístico por meio de mediana e testes não paramétricos de Mann Whitney e Kruskal Wallis. Estimou-se um valor mediano de 20 dias para o atraso geral dos doentes, verificando-se que os indivíduos solteiros, com até oito anos de estudo e desempregados foram os que mais demoraram a procurar um serviço de saúde (30 dias). O modelo teórico confirmou a presença de fatores predisponentes que favorecem as desigualdades na busca e obtenção de cuidados. A inclusão da dimensão subjetiva na garantia de um cuidado integral pode contribuir para renovação das práticas e redução das iniquidades dos indivíduos acometidos pela tuberculose.

DESCRITORES: Tuberculose. Diagnóstico tardio. Acesso aos serviços de saúde.

\section{LA INFLUENCIA DE LOS DETERMINANTES INDIVIDUALES EN EL RETARDO DEL DIAGNÓSTICO DE LA TUBERCULOSIS}

RESUMEN: Analiza la influencia de los determinantes individuales sobre el modelo de utilización de servicios como definidora del intervalo de tiempo que el enfermo de tuberculosis demora en buscar asistencia para descubrir su diagnóstico. Investigación seccional, realizada en capital del Noreste brasileño, involucrando 101 enfermos. Las variables fueron sometidas a tratamiento estadístico por medio de mediana y exámenes no-paramétricos de Mann Whitney y Kruskal Wallis. Se estimó un valor mediano de 20 días para el atraso general de los enfermos, verificándose que los individuos solteros, con hasta 8 años de estudio y desempleados, fueron los que más tardaron en buscar un servicio de salud (30 días). El modelo teórico confirmó la presencia de factores predispuestos que favorecen las desigualdades en la búsqueda y obtención de cuidados. La inclusión de la dimensión subjetiva en la garantía de un cuidado integral puede contribuir para renovación de las prácticas y reducción de las iniquidades de los individuos acometidos por tuberculosis.

DESCRIPTORES: Tuberculosis. Diagnóstico tardío. Accesibilidad a los servicios de salud. 


\section{INTRODUCTION}

The delay in the diagnosis of Tuberculosis (TB) has been a source of reflection and debate about the quality and opportunity of patients' access to health care, in which two types of delay can be linked: the "patient's delay", which refers to the duration between the start of the symptoms and the first visit to a health service, and the "health system delay", related to the time between the first contact with a care service and the confirmation of the TB diagnosis. ${ }^{1-4}$

Based on research involving the theme, there is no unanimous concept of what could constitute a "diagnostic delay", indicating that an "acceptable" delay depends on the health services, the community's profile and the local epidemiological situation. ${ }^{5}$ The causes of delay in the TB diagnosis differ according to the reality of each region, but cannot be exclusively attributed to the barriers the health services impose.

A study ${ }^{6}$ indicates the individual characteristics of the population at risk as determinants of the disease and health service usage process. The model the authors propose is based on three categories: predisposition, availability, and need, adding previous use.

The first component, predisposition, consists of the characteristics that describe the individuals' proneness or trend to visit the health service. They precede the disease episode, are intrinsically linked to the subject and include factors like age, gender, race/color, religion/creed, education. The second component, availability, is related to the means or tools people have to use the health service. These resources can be specific to the individual or family, such as income and social security, besides the attributes of the com- munity the individual lives in (urban region/ rural region). The third component, needs, refers to the perception level of the disease, which constitutes the most immediate reason to seek a health service ${ }^{6}$, and the final component is the previous use of health services, which permits understanding the population's usage patterns and ranges from the way the network is organized to attend to the demand to the community's answers to the care obtained.

The acknowledgement that the health situation and the service use vary significantly depending on the context and singularities of each individual sheds light on the importance of accessibility as an instrument that can direct interventions, identifying the factors that hamper the search for and obtainment of care.

To express that the distinct characteristics of the population can determine the possibility to enter the health system or not, a new diagram is scheduled to relate the indicators surveyed with the central research problem, the delay in the TB diagnosis, with a focus on the patient's perspective (Figure 1).

It is based on the premise that individuals with suspicions of TB have individual attributes that determine their health care search behavior and, consequently, directly influences the time interval (s)he takes to seek health care to discover their diagnosis.

To identify aspects of the subjects' singularity that can influence the access to the health service, this study analyze the time between the appearance of the signs and symptoms of TB and search for the first health service according to the indicators proposed by Aday and Andersen. ${ }^{6}$ 


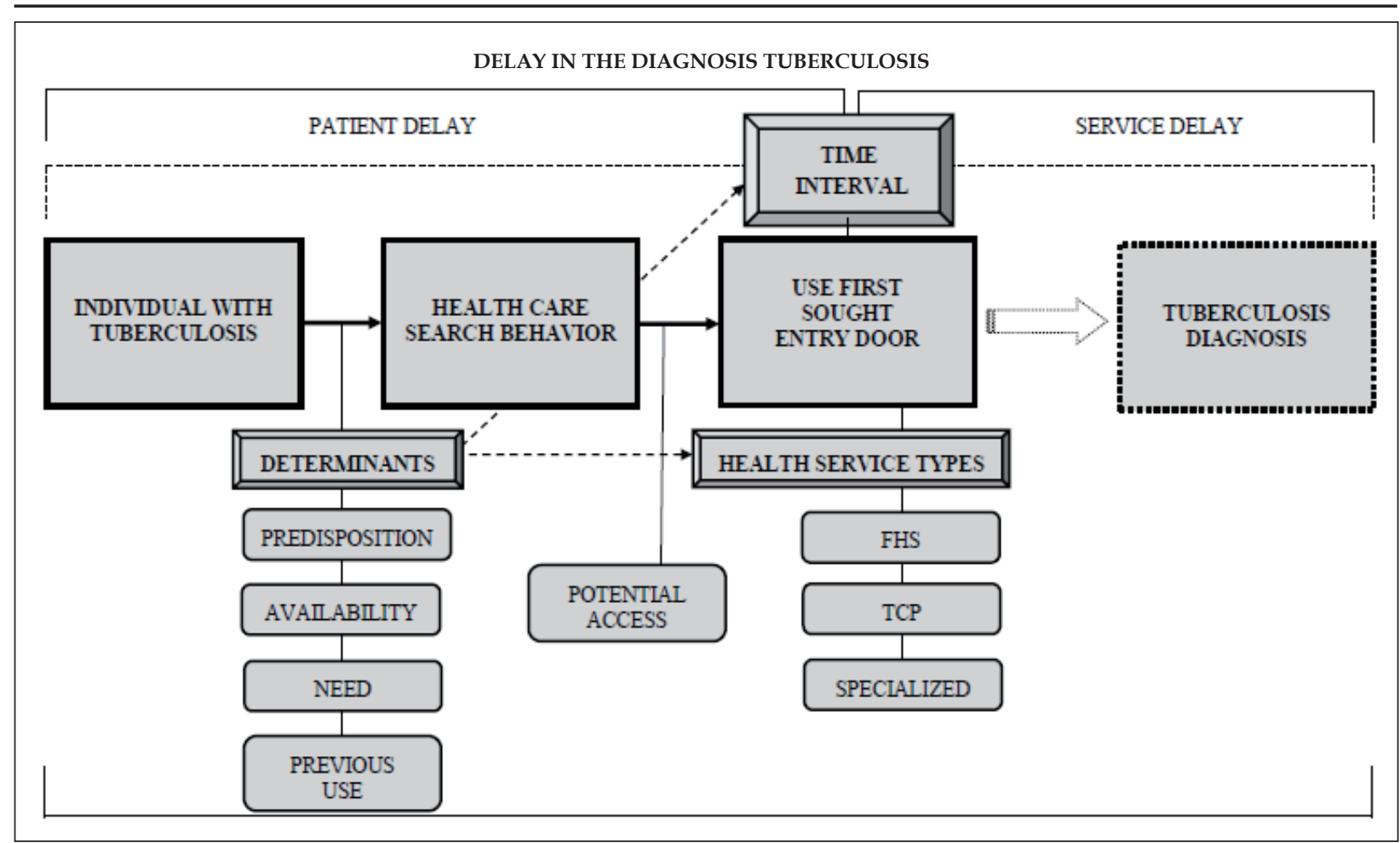

FHS: Family Health Service; TCP: Tuberculosis Control Program Outpatient Clinic.

Figure 1 - Study diagram of the delay in the tuberculosis diagnosis from the perspective of patient delay

\section{MATERIALS AND METHOD}

Epidemiological, cross-sectional and quantitative survey undertaken in João Pessoa-PB, selected by the Ministry of Health as a priority city for tuberculosis control. The city has 702,234 inhabitants and organizes health care in a regional manner, in five Health Districts, with 180 Family Health Services (FHSs), totaling a coverage rate of $84 \%$. For the cases of TB, two entry doors coexist in the city: FHS and specialized outpatient clinic of the Complexo Hospitalar Clementino Fraga $(\mathrm{CHCF})$, considered a referral institution in the state for the diagnosis and treatment of the disease.

The study universe consisted of patients under TB treatment living in João Pessoa, excluding patients under 18 years of age and the prison population. The estimated sample size was calculated through the software Statistic (using the commands Several means, ANOVA, 1-Way), in view of the parameter: probability of type I error $=0.05$; probability of type II error $=0.20$; and variation due to error $=0.2$, it was determined that 100 informants would be necessary. ${ }^{7}$ The cases were selected on a convenience base, due to the need to collect data from all patients under treatment.
The data were collected between July and October 2009 through a primary source - interviews with patients. The questionnaire used was adapted and validated ${ }^{8}$ containing assessment indicators of the TB control actions in the Primary Health Care context. For this study, 17 variables were selected, based on the individual axis of access determinants proposed by Aday and Andersen ${ }^{6}$, and which adapted to the indicators "predisposition", "availability", "need" and "previous use". Predisposition: sex, age, race/color, marital status, belief or religion and education. Availability: occupation, monthly income and number of people depending on the income. Need: frequency of watching commercials / campaigns / educative work before getting ill, whether someone in the family was treated against TB, assessment of TB knowledge before getting ill and symptom intensity. Previous use: first place visited during earlier disease episodes; frequency of visiting health services for preventive control; frequency of visiting health services for routine consultations/tests; and frequency of visiting nearest health service in case of illness.

The data were typed and stored in an electronic worksheet in Microsoft Office Excel 2003 
and later transferred to the data entry table of the software Statsoft Statistica 9.0. The statistical analysis to calculate the time in days between the appearance of the first signs and symptoms of TB and the first health service visit was based on a central trend measure: the median. To identify a statistically significant association between the median values and individual determinants, Mann-Whitney and Kruskal-Wallis' non-parametric test were applied.

Approval for the research was obtained from the Research Ethics Committee at Universidade Federal da Paraíba (UFPB), under protocol 0589. The secrecy of the information was guar- antee and the interviewees were asked for their written consent.

\section{RESULTS}

The analysis of the time in days between the start of the disease symptoms and the first health service visit, according to the variables related to the indicator "predisposition", reveal sufficient evidence to reject the assertion that the variables "marital status" and "education" have response categories with the same medians $(p=0.0083$ and 0.0385 , respectively) and, consequently, at least one of the medians seems to be different (Table 1 ).

Table 1 - Media time in days the patient took to visit the first health service, according to the variables related to the indicator "predisposition". João Pessoa-PB, 2009

\begin{tabular}{|c|c|c|c|c|c|}
\hline \multirow{2}{*}{$\begin{array}{l}\text { Sociodemographic variables of TB } \\
\text { patients }\end{array}$} & \multicolumn{5}{|c|}{$\begin{array}{l}\text { Time between the onset of the disease symptoms and the first visit to a } \\
\text { health service }\end{array}$} \\
\hline & $\mathbf{n}$ & $(\%)$ & Median & Quartile 25 and 75 & p \\
\hline \multicolumn{6}{|c|}{ 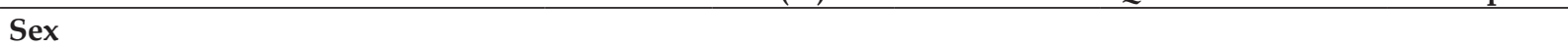 } \\
\hline Female & 28 & 27.7 & 25.5 & {$[7.5 ; 52.5]$} & \multirow[t]{2}{*}{0.7772} \\
\hline Male & 73 & 72.3 & 20.0 & {$[7.0 ; 60.0]$} & \\
\hline \multicolumn{6}{|l|}{ Age range } \\
\hline Up to 40 years & 57 & 56.4 & 30.0 & {$[8.0 ; 60.0]$} & \multirow{3}{*}{0.1599} \\
\hline Over 40 and under 60 & 31 & 30.7 & 20.0 & {$[7.0 ; 40.0]$} & \\
\hline 60 years or older & 13 & 12.9 & 8.0 & {$[7.0 ; 30.0]$} & \\
\hline \multicolumn{6}{|l|}{ Race/Color $(n=97)^{*}$} \\
\hline White & 22 & 22.7 & 15.0 & {$[7.0 ; 30.0]$} & \multirow{3}{*}{0.5928} \\
\hline Black & 19 & 19.6 & 20.0 & {$[7.0 ; 40.0]$} & \\
\hline Mulatto & 56 & 57.7 & 30.0 & {$[8.0 ; 60.0]$} & \\
\hline \multicolumn{6}{|l|}{ Marital status } \\
\hline Single & 45 & 44.6 & 30.0 & {$[15.0 ; 90.0]$} & \multirow{3}{*}{0.0083} \\
\hline Married/Fixed partner & 50 & 49.5 & 15.0 & {$[7.0 ; 30.0]$} & \\
\hline Separated/Divorced/Widowed & 6 & 5.9 & 6.5 & {$[3.0 ; 8.0]$} & \\
\hline \multicolumn{6}{|l|}{ Belief or religion $(n=97)^{*}$} \\
\hline No religion & 19 & 19.6 & 15.0 & {$[7.0 ; 45.0]$} & \multirow{3}{*}{0.7158} \\
\hline Catholic & 52 & 53.6 & 25.0 & {$[8.0 ; 60.0]$} & \\
\hline Evangelic & 26 & 26.8 & 17.5 & {$[7.0 ; 60.0]$} & \\
\hline \multicolumn{6}{|l|}{ Education } \\
\hline Up to 8 years & 65 & 64.4 & 30.0 & {$[14.0 ; 60.0]$} & \multirow{3}{*}{0.0385} \\
\hline More than 8 years & 21 & 20.8 & 14.0 & {$[5.0 ; 30.0]$} & \\
\hline No education & 15 & 14.8 & 8.0 & {$[5.0 ; 30.0]$} & \\
\hline
\end{tabular}

${ }^{*}$ Excluding response categories without statistically significant values $(\mathrm{n}<5)$.

As verified, single individuals with up to eight years of education took the longest to visit a health service when they perceived they were ill, with a median 30 days in both cases.

As to whether the economic profile influences the time interval between the perceived disease and the search for medical care, a statistically sig- nificant difference is identified in the median values for the variable "employment situation" only $(\mathrm{p}=0.0232)$ (Table 2$)$. It was observed that patients who were unemployed, on leave or housewives took more than 30 days to seek an entry door into the health system when compared to employed, self-employed or retired patients. 
Table 2 - Median time in days the patient took to visit the first health service, according to the variables related to the indicator "availability". João Pessoa-PB, 2009 (n=101)

\begin{tabular}{|c|c|c|c|c|c|}
\hline \multirow[t]{2}{*}{ Economic variables of TB patients } & \multicolumn{5}{|c|}{$\begin{array}{c}\text { Time between the onset of the disease symptoms and the first visit } \\
\text { to a health service }\end{array}$} \\
\hline & $\mathbf{n}$ & $(\%)$ & Median & Quartile 25 and 75 & p \\
\hline \multicolumn{6}{|l|}{ Employment situation } \\
\hline Unemployed & 33 & 32.7 & 30.0 & {$[15.0 ; 90.0]$} & \multirow{4}{*}{0.0232} \\
\hline Employed/Autonomous & 34 & 33.7 & 15.0 & {$[8.0 ; 30.0]$} & \\
\hline Retired & 17 & 16.8 & 8.0 & {$[5.0 ; 15.0]$} & \\
\hline Others* & 17 & 16.8 & 30.0 & {$[14.0 ; 60.0]$} & \\
\hline \multicolumn{6}{|l|}{ Monthly family income } \\
\hline Up to 0.5 minimum wage & 12 & 11.9 & 35.0 & {$[17.5 ; 105.0]$} & \multirow{3}{*}{0.2171} \\
\hline Between 0.5 and 1 minimum wage & 39 & 38.6 & 20.0 & {$[8.0 ; 60.0]$} & \\
\hline More than 1 minimum wage & 50 & 49.5 & 15.0 & {$[7.0 ; 30.0]$} & \\
\hline \multicolumn{6}{|c|}{ Number of people depending on the income } \\
\hline Up to 3 people & 35 & 34.6 & 30.0 & {$[8.0 ; 45.0]$} & \multirow{3}{*}{0.1795} \\
\hline Between 4 and 6 people & 53 & 52.5 & 15.0 & {$[7.0 ; 45.0]$} & \\
\hline More than 7 people & 13 & 12.9 & 30.0 & {$[15.0 ; 150.0]$} & \\
\hline
\end{tabular}

When assessing the relation between variables related to the "need" indicator and the time to seek health care, the results show that the knowledge profile did not determine an early or delayed search among the TB patients, as all variables present equivalent medians $(p>0.05)$ (Table 3).

Table 3 - Median time in days the patient took to visit the first health service, according to the variables related to the indicator "need". João Pessoa-PB, 2009 (n=101)

\begin{tabular}{lccccc}
\hline Knowledge variables of TB patients & \multicolumn{5}{c}{ Time between onset of disease symptoms and first visit to a health } \\
& $\mathbf{n}$ & $\mathbf{( \% )}$ & Median & Quartile 25 and 75 & p \\
\hline Access to commercials/educative activities & & & & & \\
Never & 48 & 47.5 & 15.0 & {$[7.0 ; 60.0]$} & 0.7185 \\
$\begin{array}{l}\text { Sometimes } \\
\text { Always }\end{array}$ & 32 & 31.7 & 30.0 & {$[8.0 ; 60.0]$} & \\
Earlier treatment for TB in relatives & 21 & 20.8 & 30.0 & {$[8.0 ; 30.0]$} & \\
Yes & & & & & \\
No & 36 & 35.6 & 20.5 & {$[7.5 ; 60.0]$} & 0.9182 \\
Does not know & 60 & 59.4 & 20.0 & {$[7.0 ; 52.5]$} & \\
Earlier knowledge about TB (n=97)* & 5 & 5.0 & 20.0 & {$[8.0 ; 30.0]$} & \\
Bad & & & & & \\
Regular & 80 & 82.5 & 20.0 & {$[7.5 ; 52.5]$} & 0.5691 \\
Symptom intensity & 17 & 17.5 & 30.0 & {$[7.0 ; 60.0]$} & \\
Weak & & & & & \\
Moderate & 8 & 7.9 & 32.5 & {$[8.5 ; 60.0]$} & 0.5649 \\
Strong & 20 & 19.8 & 30.0 & {$[9.0 ; 90.0]$} & \\
\hline
\end{tabular}

* Excluding response categories without statistically significant values $(\mathrm{n}<5)$.

The same happens when the time interval is analyzed with regard to the TB patients' earlier use of the health system (Table 4). Visiting a health service or not before the disease episode did not determine any disparities between the number of days of each variable related to this indicator, showing proportional medians $(\mathrm{p}>0.05)$. 
Table 4 - Median time in days the patient took to visit the first health service according to the variables related to the indicator "earlier use". João Pessoa-PB, 2009 (n=101)

\begin{tabular}{|c|c|c|c|c|c|}
\hline \multirow{2}{*}{$\begin{array}{l}\text { Variables related to earlier health } \\
\text { service use }\end{array}$} & \multicolumn{5}{|c|}{ Time between onset of disease symptoms and first visit to a health service } \\
\hline & $\mathbf{n}$ & $(\%)$ & Median & $\begin{array}{l}\text { Quartile } 25 \text { and } \\
75\end{array}$ & $\mathrm{p}$ \\
\hline \multicolumn{6}{|c|}{ First place visited during earlier disease episodes } \\
\hline Health services & 63 & 62.4 & 20.0 & {$[7.0 ; 40.0]$} & \multirow{3}{*}{0.2090} \\
\hline Others* & 10 & 9.9 & 15.0 & {$[8.0 ; 20.0]$} & \\
\hline None & 28 & 27.7 & 32.5 & {$[7.5 ; 120.0]$} & \\
\hline \multicolumn{6}{|c|}{ Visit to health service for preventive control } \\
\hline Always & 23 & 22.8 & 30.0 & {$[14.0 ; 60.0]$} & \multirow{3}{*}{0.7749} \\
\hline Sometimes & 21 & 20.8 & 21.0 & {$[14.0 ; 45.0]$} & \\
\hline Never & 57 & 56.4 & 15.0 & {$[7.0 ; 60.0]$} & \\
\hline \multicolumn{6}{|c|}{ Frequency of visits to health services near place of residence for routine consultation/test } \\
\hline Always & 22 & 21.8 & 25.5 & {$[8.0 ; 30.0]$} & \multirow{3}{*}{0.6354} \\
\hline Sometimes & 16 & 15.8 & 17.5 & {$[7.0 ; 30.0]$} & \\
\hline Never & 63 & 62.4 & 20.0 & {$[8.0 ; 60.0]$} & \\
\hline \multicolumn{6}{|c|}{ Visited the health service nearest to the place of residence when ill } \\
\hline Yes & 52 & 51.5 & 20.5 & {$[7.0 ; 60.0]$} & \multirow[t]{2}{*}{0.9757} \\
\hline No & 49 & 48.5 & 15.0 & {$[8.0 ; 60.0]$} & \\
\hline
\end{tabular}

* The category "others" refers to religious locations, folk healers or pharmacists.

Concerning the time between the onset of the TB symptoms and the first visit to a health service, independently of the individual determinants, a median value of 20 is found, with a first quartile corresponding to 7 and a third quartile to 60 days. Outliers were observed, identifying a delay of up to one year to seek care.

\section{DISCUSSION}

Some studies show that the delay between the onset of the symptoms and the user's first contact with a health professional is greater among male users. ${ }^{9-13}$ The difference in social roles between men and women is indicated as a determinant of distinct risks of exposure or access to health care. In a study undertaken in Tamil Nadu, Southern India, it is observed that employed men face difficulties to get a leave of absence from work to visit the services. Among women, the time available to visit the health services during functioning hours and the opportunity to visit the services for the purpose of their children's health are indicated as strong conditioning factors of service usage. ${ }^{9}$

This evidence may also be related to the naturalized model of masculinity, in which the male body is considered as resistant and strong for work, capable of facing any difficulty to perform its function as family provider, causing a delay to identify men's needs and to seek health care. ${ }^{14}$
Other differences in sex and gender roles can influence the development and outcome of TB when analyzed from a behavioral perspective, such as bad eating, alcohol abuse, smoking and drugs, which may result in reduced immunity and, consequently, in the emergence of the disease. A study developed in India found that the risk of progression from the infection to pulmonary $\mathrm{TB}$ corresponded to $8.6 \%$ in men and $3.1 \%$ in women, highlighting that almost all alcoholics and smokers were male. In a detailed analysis, which excluded this group (alcoholics and smokers), the relation between the infection progression between men and women was limited. ${ }^{15-16}$

Brazilian studies highlight that the presence of women at primary care services is more frequent than that of men. ${ }^{10-11}$ This is attributed to the male behavior, in two senses: socialization (time for work, going out with friends, nighttime pleasure, etc.) and the care process detached from male practice. ${ }^{12-13}$

This phenomenon is not a rule though, differs among locations and translates distinct cultural expressions. In Vietnam for example, women take longer to visit a health service, turn to low-quality establishment, tend to self-medicate and get isolated out of fear of suffering from the stigma of the disease. ${ }^{17}$

Nevertheless, in this study, longer time to visit a health services when compared to the mean time was not found between women and 
men. Similarly, the age range did not influence this time, differently from international studies in which the search for health care was associated with populations over 45 years of age and with old age. ${ }^{4-5}$

What race/color is concerned, it is known that the chance of catching TB is twice as high among black than among white people. ${ }^{18}$ This group has a lower education level, low remuneration, lower position in the job market, precarious housing conditions and reduced access to health services. ${ }^{19}$ In Brazil, a study ${ }^{20}$ indicates that white people have a $3 \%$ higher chance of consuming health services and that their socially favorable situation puts better health resources at their disposal. In the study, it is observed that $50 \%$ of the white patients started their trajectory in the health system through specialized services, mostly private consultations subject to direct payment. Nevertheless, no association was identified between the variable race/color and the type of health service sought, also because the condition of "being poor" equals them.

As regards the influence of the marital status to obtain health care, studies show a higher prevalence of medical consultations among men who are married or live with a fixed partner..$^{21-22}$ These findings legitimize the results found in this research, in which the variable marital status determined a longer time to seek health care in the category of single individuals (30 days of delay).

Concerning religion, it was observed that the patients follow the predominant trends in the country: Catholic and evangelical. Despite the scientific controversies related to spirituality and the health area, it is known that beliefs can make people assume extreme attitudes in life. In the coping process with disease or health problems, they can exclusively turn to spiritual/religious resources, ignoring medical help and the use of therapeutic technologies. Despite the possibility that these risks with alter the behavioral pattern in search of health care, in this study, the variable religion did not influence statistically significant differences in the time to seek health care.

With respect to the education level, studies indicate that individuals with lower education levels are less prone to using health services, which consequently interferes in the disease identification process. ${ }^{1-2}$ These indications ratify the present study result by showing that, among the patients with low education levels, the median time to seek care was 30 days.
The second indicator analyzed, availability, showed that $11.9 \%$ of the TB patients investigated live on less than half a minimum wage and $38.6 \%$ on less than a minimum wage, corresponding to $50.5 \%$ of all interviewees surviving on an insignificant income, with equivalent percentages of employed/self-employed and unemployed patients. The economic situation is further aggravated in numerous families, which depend on far too small financial support.

The sociocultural and economic influences have been widely discussed as factors predisposing to the delay in the TB diagnosis. ${ }^{23-26}$ The stigma, the poverty, the non-acceptance of the disease, the impossibility to be absent from one's job to attend the health service and/or to pay transportation to attend the consultations contribute to this problem. ${ }^{3}$

A study undertaken in Shanghai showed that low-income, marginalization and lack of clinical evidence of $\mathrm{TB}$, like the hemoptysis indicator, contribute to a mean delay of 21 days for the TB diagnosis. ${ }^{3}$

In this context, the income was not associated with the TB patient's delay. Nevertheless, the employment situation determined an extension of the time to seek medical care among patients who were unemployed, on leave or housewives, in line with a Brazilian study undertaken in Recife-PE, which showed that the unemployment conditions was significantly associated with the patient's delay to get $\mathrm{TB}$ care. $^{27}$

As regards the third indicator studied, need, the literature indicates that the self-perceived health generates service use. Understanding the severity of the problem and the need for curative interventions provides the citizens with a critical sense of their condition and turns them into active agents in this event. In the case of TB, studies have indicated that perceived physiopathological alterations, such as cough, weight loss, hemoptysis, led to greater agility to obtain care. ${ }^{1,3,27}$ On the other hand, the lack of understanding legitimizes the patient's passiveness or provides inappropriate directions as to what should be done in view of the problem. These conditions can enhance the diagnostic delay, as evidenced in a study undertaken in Ethiopia, in which long delays were influenced by the lack of perception of the need for health care. ${ }^{28}$

Although no association has been found between the variables of the patient's knowledge and the time spent to visit a health service, 
it is noteworthy that, according to $82.5 \%$ of the patients, the knowledge about the disease was considered bad, even though a small part had had contact with a TB patient in the family. An even more concerning finding is that educational actions remain negligible and that the search for health care was predominantly due to the worsening of symptoms, that is, after a relevant period of disease.

This knowledge gap and the consequent lack of autonomy to manage the health-disease process create room to discuss the fourth indicator - earlier use of health services. Among the interviewed patients, it was verified that $62.4 \%$ had previously used the health services for illnesses that happened before the TB. On the opposite, $56.4 \%$ had never visited the health service for preventive control, indicating low insertion of primary care services in these individuals' daily life.

It is expected that, based on the frequent use of the same service, a bond and trust are created between users and the team, permitting greater interaction and their influence in the community health situation, such as the early identification of a health problem. Nevertheless, the frequent health service use did not determine a shorter time to discover TB in this research.

Similarly, the variable related to the proximity of the service to the patient's home would be expected to influence the time spent to visit the first health services to diagnose the TB. Studies indicate that the geographical location and consequent difficulty to access the health services causes a search for non-formal care providers or the adoption of alternative practices to fight the symptoms, resulting in long delays before the disease is diagnosed..$^{2,4,28}$ Nevertheless, in this study, no evidence was found of an association between the length in days it took for the patient to visit the health service and the location of the service modalities under investigation.

A study that analyzed the mean delay to get diagnosed between peripheral and highincome countries found a variation from 4.9 to 162 days of delay between the onset of the symptoms and the first health service consultation, with a median 31.7 days among the 46 peripheral countries and 25.8 days in the 10 high-income countries, proving statistically similar delays (p-value 0.637). ${ }^{29}$

When comparing the research findings ${ }^{29}$ with the median value found in this study (20 days of delay), equivalent delays were found in the two groups of countries investigated: Ethiopia (1998) - 15 days, India (1997-1998) - 20 days, India (2003) - 21 days; China (2006) - 19 days, Malaysia (1994) - 15 days, Japan (1997) - 21 days, United States (1994) - 25 days and Hong Kong (2004) - 20 days.

Nevertheless, what is relevant is not that the number of months or days is inferior or superior to an expected delay patterns, but the individual and collective consequences of each minute an active TB patient spends without the care needed. The knowledge of the communities' reality, also including vulnerable institutions like the prison system $^{30}$ and the way its individuals lead their life can strengthen the relations between teams/users and promote agility in the search and obtainment of care.

\section{CONCLUSION}

When analyzing the median time in days it took for TB patients to visit health services, a statistically significant difference was found in the median scores of the variables "marital status" $(p=0.0083)$, "education" $(p=0.0385)$ and "employment situation" $(\mathrm{p}=0.0232)$. Single individuals, with up to eight years of education and unemployed, on leave or housewives took longest to visit a health service (30 days).

The theoretical model used confirmed the presence of predisposing factors that favor the inequalities in the search for and obtainment of care. Nevertheless, the interpretation of the selected variables does not consider the variability and dynamics of their concrete social meanings. One of the limitations in the study of associations is that it decomposes the whole into parts, mutually associated by linear cause-and-effect relations, and thus deal with a conditional positivity inherent in a discourse that abstracts the variability, complexity and dynamics of the meanings of social practices in which these disease possibilities are lived and experienced.

Acknowledging that the disease control actions gain different shapes in function of the subjects' singularities and their scenarios, it is expected that the daily work of the health teams starts to include systematic search routines and processes of the health needs and that skills are developed to acknowledge the appropriateness of the supplies to the specific context in which the encounter between the subjects and the team takes place. 


\section{REFERENCES}

1. Golub JE, Bur S, Cronin WA, Gange S, Baruch N, Comstock GW, et al. Patient and health care system delays in pulmonary tuberculosis diagnosis in a low-incidence state. Int J Tuberc Lung Dis. 2005 Set; 9(9):992-8.

2. Salaniponi FML, Harries AD, Banda HT, Kang' ombe C, Mphasa N, Mwale A, et al. Care seeking behaviour and diagnostic processes in patients with smear-positive pulmonary tuberculosis in Malawi. Int J Tuberc Lung Dis. 2000 Abr; 4(4):327-32.

3. Wang W, Jiang Q, Abdullah ASM, Xu B. Barriers in accessing to tuberculosis care among non-residents in Shanghai: a descriptive study of delays in diagnosis. Eur J Public Health. 2007 Out; 17(5):41942.

4. Yimer S, Bjune G, Alene G. Diagnostic and treatment delay among pulmonary tuberculosis patients in Ethiopia: a cross sectional study. BMC Infect Dis. 2005 Dez; 5(112):1-7.

5. Ward J, Siskind V, Konstantinos A. Patient and health care system delays in Queensland tuberculosis patient 1985-1998. Int J Tuberc Lung Dis. 2001 Nov; 5:1021-7.

6. Aday LA, Andersen R. A framework for the study off access to medical care. Health Serv Res [online]. 1974 [acesso 2011 Out 14]; 9(3):208-20. Disponível em: http:/ / www.ncbi.nlm.nih.gov/pmc/articles/ PMC1071804/

7. Hair Junior JF, Anderson RE, Tatham RL, Black WC. Análise multivariada de dados. Porto Alegre (RS): Bookman; 2005.

8. Villa TCS, Ruffino Netto A. Questionário para avaliação de desempenho de serviços de atenção básica no controle da TB no Brasil. J Bras Pneumol. 2009 Jun; 35(6):610-2.

9. Balasubramanian R, Garg R, Santha T, Gopi PG, Subramani R, Chandrasekaran V, et al. Gender disparities in tuberculosis: report from a rural DOTS programme in south India. Int J Tuberc Lung Dis. 2004 Mar; 8(3):323-32.

10. Pinheiro RS, Viacava F, Travassos C, Brito AS. Gênero, morbidade, acesso e utilização de serviços de saúde no Brasil. Ciênc Saúde Coletiva. 2002; 7(4):687-707.

11. Figueiredo W. Assistência à saúde dos homens: um desafio para os serviços de atenção primária. Ciênc Saúde Coletiva. 2005, 10(1):105-9.

12. Courtenay WH. Constructions of masculinity and their influence on men's well-being: a theory of gender and health. Soc Sci Med. 2000 Mai; 50(10):1385-401.

13. Sá LD, Santos ARBN, Oliveira AAV, Nogueira JA, Tavares LM, Villa TCS. O cuidado à saúde da mulher com tuberculose na perspectiva do enfoque familiar. Texto Contexto Enferm. 2012; Abr-Jun; 21(2):409-17.
14. Costa-Júnior FM, Maia ACB. Concepções de homens hospitalizados sobre a relação entre gênero e saúde. Psic Teor Pesq. 2009 Jan-Mar; 25(1):55-63.

15. World Health Organization. Gender and tuberculosis. Geneva (SW): WHO; 2002.

16. World Health Organization. Gender in tuberculosis research. Geneva (SW): WHO; 2004.

17. Thorson A, Hoa NP, Long NH. Health-seeking behavior of individuals with a cough of more than 3 weeks. Lancet. 2000 Nov; 356(9244):1823-4.

18. Programa Nacional por Amostras de Domicílios (PNAD) [online]. Relação entre a ocorrência de tuberculose e um conjunto de fatores socioeconômicos, demográficos e de saúde da população brasileira usando a PNAD 2003. 2010 [acesso 2010 Dez 10]. Disponível em: http:/ / www. ime.unicamp.br/sinape/sites / default/files / Trabalho_19Sinape.PDF

19. Batista LE. Mulheres e homens negros: saúde, doença e morte [tese]. Araraquara (SP): Universidade de São Paulo. Faculdade de Ciências e Letras; 2002.

20. Neri M, Soares W. Desigualdade social e saúde no Brasil. Cad Saúde Pública. 2002; 18(Supl):77-87.

21. Bastos GAN, Duca GFD, Hallal PC, Santos IS. Utilização de serviços médicos no sistema público de saúde no Sul do Brasil. Rev Saúde Públ. 2011 Abr; 45(3):475-84.

22. Parslow R, Jorm A, Christensen H, Jacomb P, Rodgers B. Gender differences in factors affecting use of health services: an analysis of a community study of midle-aged and older Australians. Soc Sci Med. 2004 Nov; 59(10):2121-9.

23. Needham DM, Godfrey-Faussett P, Foster SD. Barriers to tuberculosis control in urban Zambia: the economic impact and burden on patients prior to diagnosis. Int J Tuberc Lung Dis. 1998 Out; 2(10):811-7.

24. Lawn SD, Afful B, Acheampong JW. Pulmonary tuberculosis: diagnostic delay in Ghanaian adults. Int J Tuberc Lung Dis. 1998 Ago; 2(8):635-40.

25. Long NH, Johansson E, Lönnroth K, Eriksson B, Winkvist A, Diwan VK. Longer delays in tuberculosis diagnosis among women in Vietnam. Int J Tuberc Lung Dis. 1999 Mai; 3(5):388-93.

26. Greene JA. An ethnography of nonadherence: culture, poverty, and tuberculosis in urban Bolivia. Cult Med Psychiatry. 2004 Set; 28:401-25.

27. Santos MAPS, Albuquerque MFPM, Ximenes RAA, Lucena-Silva NLCL, Braga C, Campelo ARL, et al. Risk factors for treatment delay in pulmonary tuberculosis in Recife, Brazil. BMC Public Health. 2005 Mar; 5(25):1-8.

28. Demissie M, Lindtjorn B, Berhane Y. Patient and health service delay in the diagnosis of pulmonary tuberculosis in Ethiopia. BMC Public Health. 2002 Set; 2:23. 
29. Sreeramareddy CT, Panduru KV, Menten J, Ende JV. Time delays in diagnosis of pulmonary tuberculosis: a systematic review of literature. BMC Infect Dis. 2009 Jun; 9:91.
30. Souza KMJ, Villa TCS, Assolini FEP, Beraldo AA, França UM, Protti ST, et al. Atraso no diagnóstico da tuberculose em sistema prisional: a experiência do doente apenado. Texto Contexto Enferm. 2012; Jan-Mar; 21(1):17-25. 